
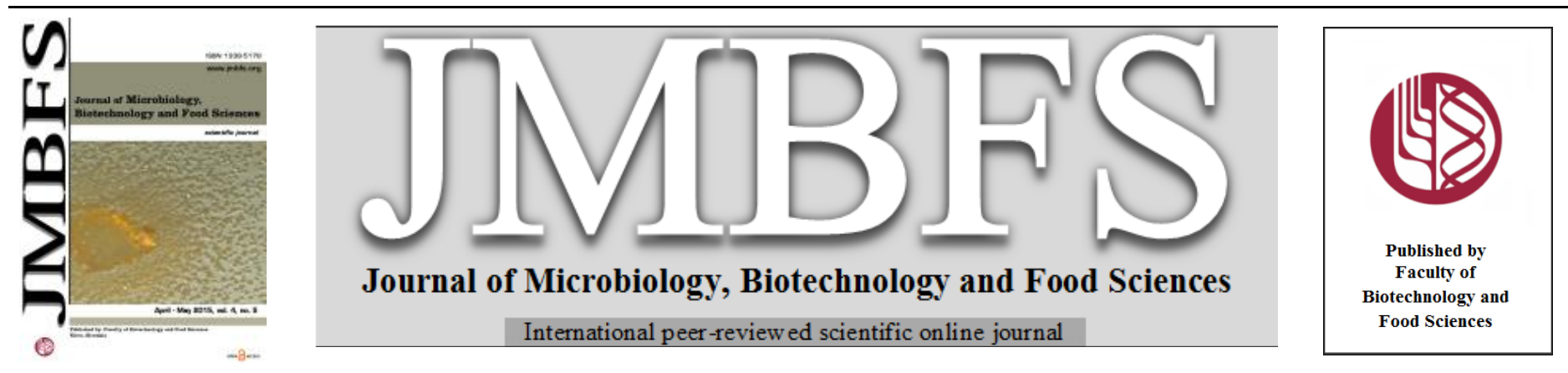

\title{
SACCHAROTHRIX SP. ABH26, A NEW ACTINOBACTERIAL STRAIN FROM ALGERIAN SAHARAN SOIL: ISOLATION, IDENTIFICATION AND ANTIMICROBIAL ACTIVITY
}

\author{
Abdelhadi Lahoum ${ }^{1}$, Noureddine Bouras ${ }^{* 1,2}$, Khaoula Bouznada ${ }^{1}$, Michael D. Holtz ${ }^{3}$, Cathrin Spröer ${ }^{4}$,Hans-Peter Klenk ${ }^{4}$, Nasserdine $^{2}$ \\ Sabaoul
}

Address(es): Dr. Noureddine Bouras (Ph.D)

${ }^{1}$ Laboratoire de Biologie des Systèmes Microbiens (LBSM), Ecole Normale Supérieure de Kouba, B.P. 92, 16050 Kouba, Algiers, Algeria. Phone number +213

21297511.

${ }^{2}$ Département de Biologie, Faculté des Sciences de la Nature et de la Vie et Sciences de la Terre, Université de Ghardaïa, BP 455, Ghardaïa 47000, Algeria.

${ }^{3}$ Field Crop Development Centre, Alberta Agriculture and Rural Development, 6000 C \& E Trail, Lacombe, Alberta, T4L 1W1, Canada.

${ }^{4}$ Leibniz Institute DSMZ-German Collection of Microorganisms and Cell Cultures, Inhoffenstraße 7B, 38124 Braunschweig, Germany.

*Corresponding author: noureddine_bouras@yahoo.fr

doi: 10.15414/jmbfs.2015.4.5.415-420

\section{ARTICLE INFO}

Received 31. 3. 2014

Revised 28. 9. 2014

Accepted 12. 2. 2015

Published 1. 4. 2015

Regular article open ${ }_{\text {access }}$

\begin{abstract}
A new strain of actinobacteria, designated $\mathrm{ABH} 26$, was isolated from a Saharan soil in the Adrar region (Algeria), by the dilution agar plating method using a chitin-vitamins B medium supplemented with polymyxin and penicillin. The morphological studies showed that this strain represents a member of the Saccharothrix genus. Phylogenetic analysis showed that this strain had 16S rRNA gene sequence similarities ranging from $97.63 \%$ (with Saccharothrix violaceirubra NBRC $102064^{\mathrm{T}}$ ) to $99.86 \%$ (with Saccharothrix xinjiangensis NBRC $101911^{\mathrm{T}}$ ). Furthermore, strain ABH26 presented a strong activity against mycotoxigenic and phytopathogenic fungi including Aspergillus carbonarius (M333), A. flavus (NRRL 3251), A. westerdijkiae (ATCC 3174), Fusarium oxysporum f. sp. lini (Fol) and $F$. solani (Fsol). Additionally, the strain exhibited an important antimicrobial activity against many strains of the pathogenic yeast Candida albicans (M2, M3 and IPA200) and against methicillin resistant Staphylococcus aureus (MRSA 639c). Thus, four solvents ( $n$-hexane, dichloromethane, ethyl acetate and $n$-butanol) were used for the extraction of produced antibiotic compounds. The highest antimicrobial activities were obtained using the butanolic extract. The thin layer chromatography (TLC) method showed two bioactive spots, named HAD1 and HAD2, which were reveled negatively by using chemical revelators (ninhydrin, naphtoresorcinol-sulfuric acid, ferrous iron chloride and formaldehyde-sulfuric). These results indicated the absence of amine group, sugar, hydroxamic acid, phenol and aromatic compound.
\end{abstract}

Keywords: Actinobacteria, Saccharothrix, 16S rRNA, antimicrobial activity, TLC, chemical revelators

\section{INTRODUCTION}

Actinobacteria are Gram-positive bacteria with $\mathrm{C}+\mathrm{G} \geq 55 \%$ (Bergey's Manual, 2012). These microorganisms have a proven capacity to produce secondary metabolites including various biologically active compounds such as antitumor (Chang et al., 2011), antioxidant (Karthik et al., 2013), immunosuppressive and antifungal agents (Berdy, 2005). Subramani and Aalbersberg (2012) estimated that approximately $70 \%$ of microbial secondary metabolites have been obtained from the actinobacteria, especially the genus Streptomyces from which a large number of antibiotics used in human therapy were obtained. Because of the increasing resistance of pathogenic microorganisms and toxicity of some antibiotics (Berdy, 1989), many researches around the world have focused on the isolation of new antibiotics. Rare actinobacteria present an excellent resource for the discovery of novel interesting antibiotics (Lazzarini et al., 2001). Therefore, various methods are applied for selective isolation of rare taxa. One of strategies used, is the exploration of extreme habitats, which are distributed on a limited basis in the natural environment. In these habitats, the microorganisms developed a specialized metabolism system to adapt to extreme conditions.

The genus Saccharothrix is among the most interesting rare actinobacteria. Since its first description (Labeda et al., 1984), it has been shown to produce a vast diversity of different metabolites, including the antiviral agent fluvirucin from Saccharothrix mutabilis (R869-90) (Tomita et al., 1991) and the antibacterial agent saccharomicin from Saccharothrix espanaensis (NRRL 15764 ${ }^{\mathrm{T}}$ ) (Singh et al., 2000). The Algerian Saharan soils, exposed to an arid climate, constitute one of the most attractive sources of several rare actinobacteria genera such as Actinomadura, Actinopolyspora, Amycolatopsis, Nocardiopsis, Saccharopolyspora and Saccharothrix (Sabaou et al., 1998). The presence of Saccharothrix genus has been detected in many samples of Algerian Saharan soils (Sabaou et al., 1998; Zitouni et al., 2004a, 2005; Boubetra et al., 2013). It has also been found that Saccharothrix strains isolated from these soils produce new antibiotics, such as dithiolopyrrolones (Lamari et al., 2002; Bouras et al.,
2008; Merrouche et al., 2011), anthracyclines (Zitouni et al., 2004b) and chloramphenicol (Aouiche et al., 2012). These promising results emphasize the need to continue the research in this direction.

During our ongoing research for new strains producing potential metabolites from Saharan soil samples, we described the isolation and identification, by conventional and molecular methods, of a new actinobacterial strain. In addition, we interpreted the production, extraction and partial purification of its antimicrobial compounds.

\section{MATERIALS AND METHODS}

\section{Soil sampling and strain isolation}

Nine soil samples were collected from three Algerian Saharan regions (Adrar, Béni-Abbès and Hoggar) and analyzed to isolate four genera of rare actinomycetes (Saccharothrix, Nocardiopsis, Actinomadura and Nonomuraea) In total, 11 actinobacterial strains were isolated. Six strains (including ABH26) with the same Nocardiopsis or Saccharothrix morphology and five strains with the same Actinomadura or Nonomuraea morphology were purified. The actinobacterial strain ABH26 was isolated from a Saharan soil collected in Adrar (Southern Algeria, latitude $27^{\circ} 52^{\prime} \mathrm{N}$, longitude $0^{\circ} 17^{\prime} \mathrm{W}$, altitude $282 \mathrm{~m}$ ). The physico-chemical analysis showed that this soil is slightly alkaline $(\mathrm{pH}=7.7)$, unsalted (electrical conductivity $=0.7 \mathrm{mS} \mathrm{cm}^{1-}$ ) and contains a low proportion of carbon $(0.62 \%)$. One gram of dry soil was suspended in $9 \mathrm{ml}$ of sterile deionized water. Serially diluted sample was prepared and aliquots $(0.1 \mathrm{ml})$ of each dilution were plated on chitin-vitamins B-agar medium recommended for isolation of rare actinobacteria (Hayakawa and Nonomura, 1987). The medium was supplemented with $80 \mathrm{mg} / \mathrm{L}$ of cycloheximide to inhibit development of invasive fungi. Tow antibacterial agents were also added, polymyxin and penicillin, each at $25 \mathrm{mg} / \mathrm{L}$. The plates were incubated at $30^{\circ} \mathrm{C}$ for three weeks. During the incubation period, all colonies were examined directly by light microscopy 
(Zeiss). One colony was isolated, designated $\mathrm{ABH} 26$, that presented micromorphological characteristics of Saccharothrix. After isolation and purification, the strain was preserved on yeast-malt-extract agar (Shirling and Gottlieb., 1966).

\section{Morphological and cultural characteristics}

Morphological and cultural characteristics of strain ABH26 were determined on the International Streptomyces Project media: yeast extract-malt extract agar (ISP2), oatmeal agar (ISP3), inorganic salts-starch (ISP4) (Shirling and Gottlieb., 1966) and the Bennett medium. After growing at $30^{\circ} \mathrm{C}$ for 14 days, morphological characteristics were observed by the naked-eye and by using a light microscopy. The ISCC-NBS color name chart (Kelly and Judd, 1976) was used to determine the colors of areal mycelium, substrate mycelium and diffusible pigments.

\section{Physiological characteristics}

Utilization of carbohydrates as sole carbon source, degradation of hypoxanthine, tyrosine, citrate and lactate were examined as described by Gordon $\boldsymbol{e t}$ al. (1974), while degradation of starch and production of nitrate reductase were evaluated according to the methods of Marchal and Bourdon (1973) and Marchal $\boldsymbol{e t}$ al. (1978), respectively. Temperature range $\left(25-52^{\circ} \mathrm{C}\right)$, tolerance to $\mathrm{NaCl}(0-7 \%$, $\mathrm{w} / \mathrm{v})$ for growth were determined on ISP2 medium.

\section{DNA extraction, PCR amplification and 16S rRNA sequencing}

Strain ABH26 was grown in ISP2 broth, and genomic DNA was extracted with a DNA extraction kit (Master Pure Gram-Positive DNA Purification kit, Epicentre Biotechnologies) as described by Li et al. (2007). PCR amplification of the $16 \mathrm{~S}$ rRNA gene sequence of strain ABH26 was performed as described by Rainey $\boldsymbol{e}$ al. (1996) by using two universal primers: $27 \mathrm{f}$ (5'AGAGTTTGATCCTGGCTCAG-3') and 1492r GGTTACCTTGTTACGACTT-3'). The PCR amplification was conducted using a thermocycler (STRATAGENE RoboCycler Gradient 96) in a $50 \mu$ containing $1.25 \mathrm{U}$ of Taq DNA polymerase, $1 \mu \mathrm{l}(500 \mathrm{ng})$ of purified DNA, $1 \times$ PCR buffer $\left(10 \mathrm{mM}\right.$ of Tris- $\mathrm{HCl}, 50 \mathrm{mmol}$ of $\mathrm{KCl}, \mathrm{pH} 9.0$ at $25^{\circ} \mathrm{C}$ ), $1.5 \mathrm{mmol}$ of $\mathrm{MgCl}_{2}, 200$ $\mu \mathrm{mol}$ of each dNTP and $1 \mu \mathrm{mol}$ of each primer. The amplification cycle consisted of three steps: an initial denaturation at $98^{\circ} \mathrm{C}$ for 3 minutes, after which Taq DNA polymerase was added, followed by 30 amplification cycles of $94^{\circ} \mathrm{C}$ for $1 \mathrm{~min}, 52^{\circ} \mathrm{C}$ for $1 \mathrm{~min}$, and $72^{\circ} \mathrm{C}$ for $2 \mathrm{~min}$, and a final extension step of $72^{\circ} \mathrm{C}$ for $10 \mathrm{~min}$. The PCR product was detected by agarose gel electrophoresis and was visualized by ultraviolet (UV) fluorescence after ethidium bromide staining. PCR products were purified with a PCR product purification kit (Qiagen). The PCR products were sequenced using the same primers as above and an automated sequencer (model 3130 Genetic Analyzer; Applied Biosystems, Foster City, CA USA) using a BigDye Terminator v3.1 Cycle Sequencing Kit (Applied Biosystems), according to the manufacturer's instructions. The sequence obtained was compared for similarity with the reference species in the public sequence databases and with the EzTaxon-e server (http://eztaxon-e.ezbiocloud.net/) (Kim et al., 2012), a web-based tool for the identification of prokaryotes based on $16 \mathrm{~S}$ rRNA gene sequences from type strains.

\section{Phylogenetic analysis}

Phylogenetic analyses were conducted using the program Molecular Evolutionary Genetics Analysis version 5, MEGA5 (Tamura et al., 2011). The 16S rRNA sequence of strain ABH26 was aligned using the CLUSTAL W program (Larkin et al., 2007) against corresponding nucleotide sequences of representatives of the Saccharothrix genus retrieved from EzTaxon-e server. Evolutionary distance was generated as described by Jukes and Cantor (1969) and a phylogenetic tree was inferred by the neighbor-joining method (Saitou and Nei, 1987). Tree topologies were evaluated by bootstrap analysis (Felsenstein, 1985), based on 1000 resamplings of the neighbor-joining dataset.

\section{Antimicrobial assay}

The target microorganisms used for determining the antimicrobial spectrum of the new actinobacterial strain were the filamentous fungi: Aspergillus carbonarius (M333), A. flavus (NRRL 3251), A. westerdijkiae (ATCC 3174), A. parasiticus (CBS 100926), Fusarium culmorum $(\mathrm{Fc}), F$. equiseti $(\mathrm{Fe}), F$. graminearum (Fg), F. oxysporum f. sp. albedinis (Foa), F. oxysporum f. sp. radicis lycopersici (Forl), F. solani (Fsol), F. sporotrichioides (Fs), Rhizoctonia solani (AG3) and Umbelopsis ramanniana (NRRL 1829). The isolates of pathogenic yeast Candida albicans (M2, M3 and IPA200) were isolated from diseased patients in two hospitals located in Algiers (hospital Bachir Mentouri and Institut Pasteur d'Alger). The target bacteria Bacillus subtilis (ATCC 4226), Escherichia coli (E52), E. coli (E195), Klebsiella pneumonia (E40) and methicillin resistant Staphylococcus aureus (MRSA 639c) were also used to search for antibacterial activity. The target microorganisms without a collection number were from our laboratory collection. The streak assay method was used for primary screening of antimicrobial activity. The strain was first cultivated in a straight line on ISP2 medium at $30^{\circ} \mathrm{C}$ for 10 days. At the end of the incubation period, the target microorganisms were seeded in streaks perpendicular to the cultured actinobacterium cultivated. Inhibition distance between target microorganisms and the actinobacterial strain were measured after incubation at $30^{\circ} \mathrm{C}$ for 24 hours for bacteria and yeasts, and 48 hours for filamentous fungi.

\section{Kinetics of antimicrobial production, $\mathrm{pH}$ and biomass}

The producing strain $\mathrm{ABH} 26$ was cultured on a rotary shaker $\left(250 \mathrm{rpm}, 30^{\circ} \mathrm{C}\right)$ for 48 hours in a $250 \mathrm{ml}$ Erlenmeyer flask containing $50 \mathrm{ml}$ of ISP2 liquid medium. Three $\mathrm{ml}$ of the seed culture was transferred into a $500 \mathrm{ml}$ Erlenmeyer flask containing $100 \mathrm{ml}$ of the same medium. The aliquots were collected each day by centrifuging (Sigma mini-centrifuges) $4 \mathrm{ml}$ of homogenized culture broth in Eppendorf tubes for $10 \mathrm{~min}$ at $16000 \times g$. The centrifugate was used for determining the evolution of biomass and the supernatant was used to determine $\mathrm{pH}$ and antimicrobial activity. The antagonistic activity against $S$. aureus, $C$. albicans, $F$. culmorum and $U$. ramanniana was evaluated every 24 hours during 12 days of fermentation by the agar diffusion method (well technique). Wells (10 $\mathrm{mm}$ in diameter) made in the ISP2 agar plates $(12 \mathrm{~g} / \mathrm{L}$ of agar) received $100 \mu 1$ of the cell-free supernatant samples. After incubation, zones of inhibition ( $\mathrm{mm}$ in diameter) were recorded.

Production, extraction, detection and chemical characterization of antimicrobial compounds

The strain $\mathrm{ABH} 26$ was cultivated in three $500 \mathrm{ml}$ Erlenmeyer flasks each containing $100 \mathrm{ml}$ of liquid ISP2 medium, and incubated at $30^{\circ} \mathrm{C}$, under constant agitation of $250 \mathrm{rpm}$. The extraction of bioactive compounds took place on the day of optimal production (at day 8 of fermentation). The fermentation broth $\left(300 \mathrm{ml}\right.$ ) was centrifuged at $8000 \mathrm{rpm}$ for $20 \mathrm{~min}$ at $25^{\circ} \mathrm{C}$ to remove the mycelium. The cell-free supernatant was divided into four equal volumes of 60 $\mathrm{ml}$, and then each was extracted with an equal volume of four organic solvents: $n$-hexane, dichloromethane, ethyl acetate and $n$-butanol. The organic extracts were evaporated to dryness under vacuum on a Rotavapor R-205 (Buchi, Switzerland). The residues were dissolved in $1 \mathrm{ml}$ of methanol and subjected to biological assay (paper disk of $6 \mathrm{~mm}$ in diameter, Institute Pasteur) against $S$. aureus, $C$. albicans and $U$. ramanniana. The disks received $60 \mu 1$ of each extract and were placed on the ISP2 medium (12 g/L agar) inoculated with target microorganism. Inhibition zones were expressed as diameter and measured after incubation at $30^{\circ} \mathrm{C}$ for 24 hours for $S$. aureus and C. albicans, and for 48 hours for $U$. ramanniana. A paper disk containing an identical volume of methanol was used as control. After that, $20 \times 20 \mathrm{~cm}$ silica gel plates (Merck Art. 5735, Kiesselgel 60HF 254-365) were prepared, and then activated at $105{ }^{\circ} \mathrm{C}$ for one hour. A volume of $60 \mu \mathrm{l}$ of each organic extract was spotted on these plates, which were developed with system solvent: ethyl acetate/methanol (100:15 v/v) The developed TLC plates were air-dried overnight at $40^{\circ} \mathrm{C}$ to evaporate all solvent. The separated compounds were visualized with the naked-eye as colored spots and also under ultraviolet (UV) at 254 (absorbance) and at $365 \mathrm{~nm}$ (fluorescence). For detecting the active spots, we used the method of Betina (1973) known as bioautography. Three TLC plates were placed in plastic bioassay dishes $\left(23 \times 23 \times 2.2 \mathrm{~cm}^{3}\right)$ and overlaid with $100 \mathrm{ml} /$ plate of ISP2 medium (containing $7 \mathrm{~g} / \mathrm{L}$ of agar) seeded with $S$. aureus, C. albicans and $U$. ramanniana, separately. After the incubation period, clear areas due to inhibition of microorganism growth indicated the location of antimicrobial compounds on the TLC plates. The retention factor (RF) values of each active spot were recorded. The antimicrobial compounds were revealed on silica gel plates using the chemical revelators: ninhydrin, naphtoresorcinol-sulfuric acid, ferrous iron chloride and formaldehyde-sulfuric acid as reported by Boudjella et al. (2006).

\section{RESULTS}

Strain ABH26 formed well-branched substrate mycelia without fragmentation on agar media. Arial mycelium is well developed and fragmented anarchically, often with zigzag into long chains of non-motile and elongated spores with different sizes, on ISP2, ISP3, ISP4 and Bennett medium (figure 1).

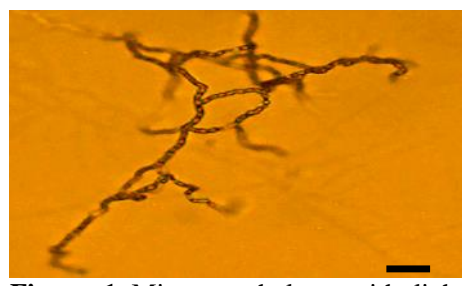

Figure 1 Micromorphology with light microscopy of spore chains of strain $\mathrm{ABH} 26$ grown on ISP2 for 10 days at $30^{\circ} \mathrm{C}$, bar $10 \mu \mathrm{m}$. 
Endospores, sclerotic granules and synnemata were not observed. ABH26 showed a good growth on ISP2, ISP3 and Bennett, and moderate growth on ISP4 medium. The color of the aerial mycelia is white to pale yellow-pink on most media; substrate mycelia are orange to yellow-brown and produce an orange soluble pigment on ISP2 but pale brown on Bennett medium. The morphological and cultural characteristics of stain $\mathrm{ABH} 26$ are given in Tab 1.

Table 1 Macromorphological characteristics of strain ABH26 on different media after 14 days of incubation

\begin{tabular}{|c|c|c|c|c|}
\hline \multirow[t]{2}{*}{ Agar medium } & \multirow[t]{2}{*}{ Growth } & \multicolumn{2}{|l|}{ Production and color of: } & \multirow[t]{2}{*}{ Soluble pigment } \\
\hline & & Aerial mycelium & Substrate mycelium & \\
\hline ISP2 & +++ & + white & Pale orange & Orange \\
\hline ISP3 & +++ & ++ to +++ yellow-pink & Orange & - \\
\hline ISP4 & + to ++ & + to ++ white-yellow & Pale orange & - \\
\hline Bennett & +++ & + to ++ yellow-pink & Yellowish gray & Moderate brown \\
\hline
\end{tabular}

+: weak, ++: moderate, +++: strong, - : no production.

The physiological studies revealed that the strain ABH26 utilized L-arabinose, Dfructose, D-glucoside, D-glucose, D-lactose, D-mannose, D-manitol, $\alpha$-methylD- glucoside, raffinose, L-rhamnose, D-sucrose and D-xylose as sole carbon source, but not adonitol, inositol, melibiose as can be seen from the physiological characters given in Tab 2. Citrate, starch and tyrosine were hydrolyzed, but acetate, hypoxanthine and lactate are not. The test was negative for production of nitrate reductase. Growth occurs at $28-45^{\circ} \mathrm{C}$ and tolerates up to $3 \%(w / v)$ of $\mathrm{NaCl}$.

Table 2 Physiological characteristics of the strain ABH26 in comparison with the most closely related species Saccharothrix xinjiangensis NBRC $101911^{\mathrm{T}}$

\begin{tabular}{lcc}
\hline \hline Tests & ABH26 & $\begin{array}{c}\text { Sacharothrix xinjiangensis } \\
\text { NBRC 101911 }^{\mathbf{T}}\end{array}$ \\
\hline Carbon source utilization: & & + \\
\hline L-arabinose & + & + \\
\hline Melibiose & - & + \\
\hline$\alpha$-Methyl-D-glucoside & + & + \\
\hline D-lactose & + & + \\
\hline Raffinose & + & + \\
\hline L-rhamnose & + & + \\
\hline D-sucrose & + & + \\
\hline D-xylose & + & \\
\hline
\end{tabular}

\begin{tabular}{lcc}
\hline Hydrolysis of: & & \\
\hline Citrate & + & - \\
\hline Lactate & - & - \\
\hline Starch & + & + \\
\hline Tyrosine & + & - \\
\hline Nitrate reduction & - & - \\
\hline Growth in the presence of: & & - \\
\hline $5 \% \mathrm{NaCl}(\mathrm{w} / \mathrm{v})$ & - & + \\
\hline Growth at $50^{\circ} \mathrm{C}$ & - & \\
\hline \hline- : negative,$+:$ positive. & &
\end{tabular}

Through 16S rRNA sequence analysis, an amplified fragment of 1438 base pairs was obtained and compared with sequences of the reference species of bacteria contained in EzTaxon-e server. Phylogenetic analysis showed that strain ABH26 had 16S rRNA gene sequence similarities ranging from $97.63 \%$ (with Saccharothrix violaceirubra NBRC $102064^{\mathrm{T}}$ ) to $99.86 \%$ (with Saccharothrix xinjiangensis $\mathrm{NBRC} 101911^{\mathrm{T}}$ ). The phylogenetic tree obtained by applying the neighbor-joining method is illustrated in figure 2. The GenBank /EMBL/DDBJ accession number for the $16 \mathrm{~S}$ rRNA gene sequence of strain $\mathrm{ABH} 26$ is KJ572276.

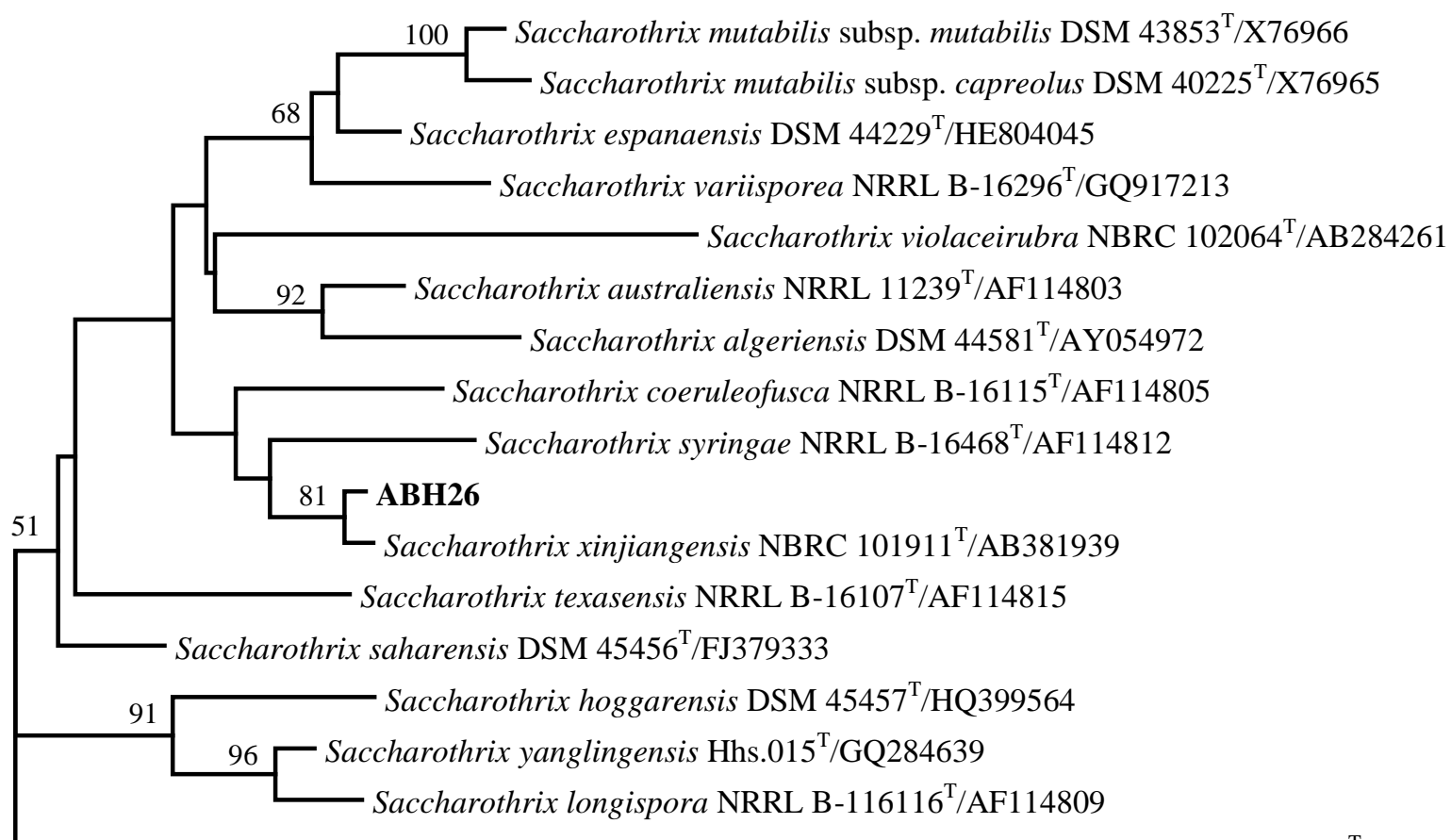

Umezawaea tangerina MK27-91F2 $2^{\mathrm{T}} / \mathrm{AB} 020031$

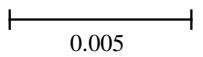

Figure 2 Phylogenic tree based on 16S rRNA gene sequences showing relationships among strain ABH26 and all type strain species of Saccharothrix. Numbers at nodes indicate percentages of bootstrap support based on neighbor-joining analysis of 1000 resampled datasets: only values above $50 \%$ are given. Bar, 0.005 substitutions per nucleotide position. 
The antimicrobial activity of strain $\mathrm{ABH} 26$ against target microorganisms is shown in Tab 3 . ABH26 presented an important activity against all filamentous fungi and yeasts tested. The strain exhibited a strong activity against the Grampositive bacterium Bacillus subtilis (ATCC 4226), a moderate activity against Staphylococcus aureus resistant to methicillin (MRSA 639c). However, almost no activity was observed against Gram-negative bacteria Escherichia coli (E52), E. coli (E195) and Klebsiella pneumonia (E40).

Table 3 Antimicrobial activity of strain $\mathrm{ABH} 26$ by the streak assay method on ISP2 medium

\begin{tabular}{|c|c|}
\hline Target microorganisms & $\begin{array}{c}\text { Inhibition zone } \\
(\mathrm{mm})\end{array}$ \\
\hline Aspergillus carbonarius (M333) & 33 \\
\hline Aspergillus flavus (NRRL 3251) & 21 \\
\hline Aspergillus westerdijkiae (ATCC 3174) & 20 \\
\hline Aspergillus parasiticus (CBS 100926) & 17 \\
\hline Fusarium culmorum $(\mathrm{Fc})$ & 28 \\
\hline Fusarium equiseti $(\mathrm{Fe})$ & 24 \\
\hline Fusarium graminearum $(\mathrm{Fg})$ & 24 \\
\hline Fusarium oxysporum f. sp. albedinis (Foa) & 27 \\
\hline Fusarium oxysporum f. sp. radicis lycopersici (Forl) & 22 \\
\hline Fusarium solani $(\mathrm{Fsol})^{*}$ & 27 \\
\hline Fusarium sporothrichioides $(\mathrm{Fs})$ & 26 \\
\hline Rhizoctonia solani $(\mathrm{AG} 3)^{* *}$ & 28 \\
\hline Umbelopsis ramanniana (NRRL 1829) & 32 \\
\hline Candida albicans (M2) & 22 \\
\hline Candida albicans (M3) & 30 \\
\hline Candida albicans (IPA200) & 23 \\
\hline Bacillus subtilis (ATCC 4226) & 22 \\
\hline Escherichia coli $(\mathrm{E} 52)$ & 0 \\
\hline Escherichia coli $($ E195) & 0 \\
\hline Klebsiella pneumonia (E40) & 0 \\
\hline Staphylococcus aureus (MRSA 639c) & 15 \\
\hline
\end{tabular}

*: Moroccan isolate, **: Canadian isolate.

During the time course of fermentation on ISP2 broth, the antimicrobial activity was evaluated against Umbelopsis ramanniana (NRRL 1829), S. aureus and Candida albicans (M3) using the agar diffusion method (well technique). The biological activity started after 2 days against the $S$. aureus and against $U$. ramanniana; however, the activity against $C$. albicans was detected on day 5 of fermentation. The maximum antifungal activity was decreased after 7 days while, the maximum activity against the bacterium and yeast was located on day 8. The $\mathrm{pH}$ varied between 6.1 and 8.2 during the fermentation. The biomass increased during the first days and reached the maximum after 4 days, then decreased after 5 days of fermentation (figure 3 ).

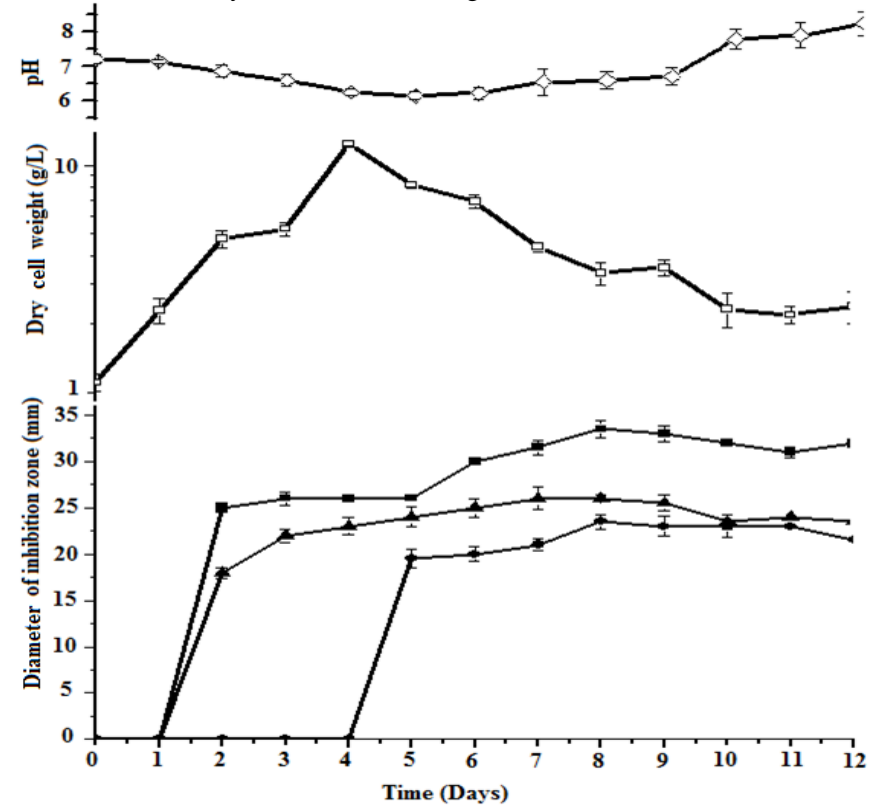

Figure 3 Kinetics of $\mathrm{pH}$, dry cell weight and antimicrobial activity against $S$ aureus (MRSA639c) (®), U. ramanniana (NRRL 1829) ( $\mathbf{\Delta}$ ) and Candida albicans (M3) (•).

After 8 days of fermentation, the antimicrobial activity of different organic solvents ( $n$-hexane, dichloromethane, ethyl acetate and $n$-butanol) was evaluated by paper disk method against $S$. aureus, $C$. albicans and $U$. ramanniana. The higher antimicrobial activities were extracted by the butanolic extract, followed by dichloromethane and ethyl acetate in comparison to methanol control which did not manifest any growth inhibitory zone. However, no activity was observed on the $n$-hexane extract. The resulting inhibition zones are illustrated in figure 4 and $\mathrm{Tab} 4$

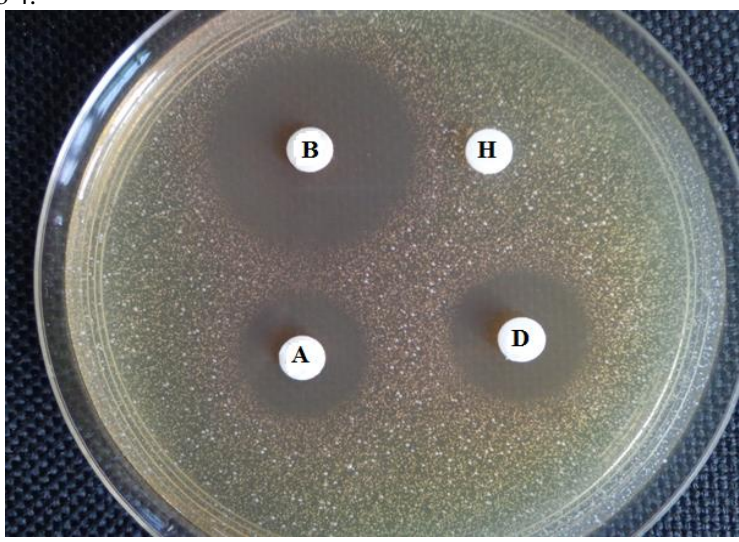

Figure 4 Antimicrobial activities of $n$-butanol (B), ethyl acetate (A), dichloromethane (D) and $n$-hexane (H) extracts against Candida albicans (M3) by paper disk method.

The profile of silica gel thin layer chromatography (TLC) showed the presence of several spots, but only those noted HAD1 and HAD2 (with retention factor values of 0.75 and 0.84 , respectively) were active. The spot HAD1 was extracted only by $n$-butanol, and showed a yellow color under UV (365 nm); however HAD2 was extracted by ethyl acetate and dichloromethane, and showed a purple blue color under UV $(365 \mathrm{~nm})$. The both spots HAD1 and HAD2 exhibited a strong activity against $S$. aureus, $C$. albicans and $U$. ramanniana, though HAD1 was more active than HAD2 (data not shown).

\section{DISCUSSION}

Various methods were used for selective isolation of rare actinobacteria, for example, by dry heating of soil samples to obtain Actinomadura strains (Zakharova et al., 2003), or by freezing of marine sediment samples to get Actinocorallia, Actinomadura, Knoellia, Glycomyces, Nocardia, Nonomuraea Pseudonocardia, Rhodococcus and Streptosporangium strains (Bredholdt et al., 2007). Particular media were also used, such as chitin-vitamins $B$ which contain chitin as sole source of carbon and nitrogen. This substrate is better degraded by actinobacteria compared to non-mycelial bacteria. Generally, rare bacteria are auxotrophic and B vitamins were added to stimulate growth. Our group research demonstrated the high selectivity of chitin-vitamins B medium to isolate new strains of rare actinobacteria, producing new potential antibiotics (Lamari et al., 2002; Zitouni et al., 2004b; Bouras et al., 2008; Merrouche et al., 2011; Aouiche et al., 2012). Other studies confirmed the performance of this medium such as Pathom-aree et al. (2006) and Zhang et al. (2010). The strain Saccharothrix sp. ABH26 was obtained on chitin-vitamins B agar supplemented by two selective agents (polymyxin and penicillin). On the basis of its morphological properties, this strain represents a member of the genus Saccharothrix. It has an aerial mycelium with anarchically fragmentation to produce long chains of non-motile and elongated spores. The 16S rRNA sequence of strain ABH26 was compared with those of other Saccharothrix species. The similarity level ranged from $97.63 \%$ with Saccharothrix violaceirubra $\mathrm{NBRC} 102064^{\mathrm{T}}$ to $99.86 \%$ with Saccharothrix xinjiangensis NBRC $101911^{\mathrm{T}}$ which is the most closely related species. According to Stackebrandt and Goebel (1994), two microorganisms have less than 97\% 16S rRNA similarity belong to the different species. However, DNA-DNA hybridization is used for species that share over of $97 \%$ similarity. In the genus Saccharothrix, many species share 16S rRNA gene similarities within the range of 97.5 to $98.9 \%$, but have levels of DNA-DNA relatedness well below $70 \%$ (the relatedness guideline proposed by Wayne et al. (1987) for delineation of separate species). For example, the type strain $S$. hoggarensis DSM $45457^{\mathrm{T}}$ exhibited $16 \mathrm{~S}$ rRNA gene sequence similarity of $98.9 \%$ with the most closely related type strain Saccharothrix longispora NRRL B-16113 ${ }^{\mathrm{T}}$ (but shared a DNA-DNA association value of 16.05\%) (Boubetra et al., 2013). In addition, the type strains of $S$ algeriensis DSM $44581^{\mathrm{T}}$ and $S$. australiensis DSM $43800^{\mathrm{T}}$ with a $16 \mathrm{~S}$ rRNA similarity value of $98.8 \%$ share a DNA-DNA relatedness value of $55.9 \%$ (Zitouni et al., 2004a). Furthermore, the studied strain Saccharothrix sp. ABH26 differs from the closely related species S. xinjiangensis NBRC $101911^{\mathrm{T}}$ not only by cultural characteristics, but also by physiological characteristics as given in Tab 2. 
Table 4 Antimicrobial activity of Saccharothrix sp. ABH26 against $S$. aureus (MRSA 639c), C. albicans (M3) and U. ramanniana (NRRL 1829) by using of different organic solvents

Zone of inhibition ( $\mathrm{mm})$ by using different solvents

\begin{tabular}{lcccc} 
Target & & & & \\
\cline { 2 - 5 } microorganism & $n$-hexane & dichloromethane & $\begin{array}{c}\text { ethyl } \\
\text { acetate }\end{array}$ & $n$-butanol \\
\hline S. aureus & 0 & 24 & 27 & 38 \\
\hline C. albicans & 0 & 20 & 19 & 31 \\
\hline U. ramanniana & 0 & 22 & 21 & 32 \\
\hline \hline
\end{tabular}

Strain ABH26 showed inhibitory activity against both Gram-positive bacteria and mycotoxigenic and phytopathogenic fungi. Several studies reported the production of several antimicrobial compounds by Sacchrothrix strains agains fungi and Gram-positive bacteria, such as a phthalate derivative (Johnson et al. 2012) and tianchimycins $A$ and $B$ (Wang et al., 2013). Strain ABH26 was also active against pathogenic strains of $C$. albicans (M3) which are known to be resistant to antibiotics amphotericine $\mathrm{B}$, cycloheximide, itraconazole, nystatine, thioconazole and terbinafine (Aouiche et al., 2012). The saccharomicins, produced by a strain of Saccharothrix espanensis (NRRL 15764), has no activity against $C$. albicans (GC 3066) (Singh et al., 2000); however, the antibiotic saccharothrixmicine produced by another strain of S. espanensis (An 113) exhibited a biological activity towards $C$. albicans (Kalinovskaya et al., 2010) The obtained results showed no activity of ABH26 against Escherichia coli (E52), E. coli (E195) and Klebsiella pneumonia (E40). In general, Gram-negative bacteria are more resistant to antibacterial compounds than Gram-positive bacteria. Several studies showed that the outer cell membrane in Gram-negative bacteria (double membranes) contains many protective mechanisms agains antibiotics (Gupta, 2011). Moreover, the increase in resistance of Gram-negative bacteria is mainly due to mobile genes on plasmids that can readily spread through bacterial populations (Carattoli et al., 2006; Carattoli, 2009). For our strain Saccharothrix sp. ABH26, the highest activities were observed after 7 to 9 days of fermentation. It means that the strain grow firstly to form a considerable amount of biomass flowed by the production of antibiotics. Several studies reported that some actinobacterial strains produce the antibiotics in the first days of fermentation, such as arylomycine which is produced by a strain of Streptomyces sp. (Tü 6075) after 3 days of incubation (Schimana et al., 2002). However, other strains produce antibiotics only after 12 days of fermentation, for instance, pradimicine $\mathrm{S}$ by a strain of Actinomadura spinosa (AA0851) (Saitoh $\boldsymbol{e}$ al., 1993). The $n$-hexane extract showed no antimicrobial activity. This shows the non-lipid nature of the bioactive metabolite(s) produced by Saccharothrix sp $\mathrm{ABH} 26$.

The active compounds HAD1 and HAD2 were revealed negatively with ninhydrin, naphtoresorcinol-sulfuric acid, ferrous iron chloride and formaldehyde-sulfuric. These results showed the absence of amine group, sugar, hydroxamic acid, phenol and aromatic compound. The chloramphenico produced by Saccharothrix sp. (PAL54) contains aromatic and amine groups (Aouiche et al., 2012), however, the mutactimycin PR produced by Saccharothrix sp. (103) contains polycyclic aromatic with amine groups (Zitoun et al., 2004b). The type strain S. espanaensis NRRL $15764^{\mathrm{T}}$ is known by its production of saccharomicins with phenol and sugars. The dithiolopyrrolone antibiotics from $S$. algeriensis DSM $44581^{\mathrm{T}}$ contains amine functions but not sugars, hydroxamic acids, phenols and aromatic compounds. S. xinjiangensis NBRC $101911^{\mathrm{T}}$, the most closely species of the strain $\mathrm{ABH} 26$ produces tianchimycin A without amines, sugars, hydroxamic acids, phenols and aromatic compounds. Unlike our active compounds, the tianchimycin A has been shown to be active against Gram-negative bacteria (Wang et al., 2013). For this, the antimicrobial compounds produced by the strain ABH26 may represent new secondary metabolites, which will be confirmed by further studies.

\section{CONCLUSION}

The results of current research revealed the taxonomic position of strain $\mathrm{ABH} 26$ as a member of Saccharothrix genus, and give support to the biotechnologica use of the rare actinobacteria as source of natural products. These molecules could be beneficial on plant and human therapy. However, further studies will be necessary to determine the structure, the activity mechanism and the toxicity of these compounds.

\section{REFERENCES}

AOUICHE, A., SABAOU, N., MEKLAT, A., ZITOUNI, A., BIJANI, C., MATHIEU, F., LEBRIHI, A. 2012. Saccharothrix sp. PAL54, a new chloramphenicol producing strain isolated from a Saharan soil. World Journal of Microbiology and Biotechnology. 28 (3), 943-951. DOI http://dx.doi.org/10.1007/s11274-011-0892-2

BERDY, J. 1989. The discovery of new bioactive microbial metabolites: screening and identification. Progress in industrial microbiology. 27, 3-27.
BERDY, J. 2005. Bioactive microbial metabolites. Journal of Antibiotics. 58 (1) 1-26. DOI: http://dx.doi.org/10.1038/ja.2005.1

Bergey's Manual of Systematic Bacteriology, GOODFELLOW, M. KAMMPFER, BUSSE, H.J., TRUJILLO, M.E., SUZUKI, K.I., LUNDWI, W; WHITMAN, W.B. 2012. The actinobacteria. Second edition. Volume 5. DOI: http://dx.doi.org/10.1007/978-0-387-68233-4

BETINA, V. 1973. Bioautography in paper and thin layer chromatography and its scope in the antibiotic field. Journal of Chromatography. 78 (1),41-51. DOI: http://dx.doi.org/10.1016/s0021-9673(01)99035-1

BOUBETRA, D., SABAOU, N., ZITOUNI, A., BIJANI, C., LEBRIHI, A., MATHIEU, F. 2013. Taxonomy and chemical characterization of new antibiotics produced by Saccharothrix SA198 isolated from a Saharan soil. Microbiological Research. 168 (4), 223-230. DOI: http://dx.doi.org/10.1016/j.micres.2012.11.005 BOURAS, N., MERROUCHE, R., LAMARI, L., MATHIEU, F., SABAOU, N., LEBRIHI, A. 2008. Precursor directed biosynthesis of new dithiolopyrrolone analogs by Saccharothrix algeriensis NRRL B-24137. Process Biochemistry. 43 (11), 1244-1252. DOI: http://dx.doi.org/10.1016/j.procbio.2008.07.008

BREDHOLDT, H., GALATENKO, O.A., ENGELHARDT, K., TJAERVIK, E., TEREKHOVA, L.P. Terekhova, ZOTCHEV, S.B. 2007. Rare actinomycete bacteria from the shallow water sediments of the Trondheim fjord, Norway: isolation, diversity and biological activity. Environmental Microbiology. 9 (11) 2756-2764. DOI: http://dx.doi.org/10.1111/j.1462-2920.2007.01387.x

CARATTOLI, A. 2009. Resistance plasmid families in Enterobacteriaceae. Antimicrob Agents Chemother. 53 (6), 2227-2238. DOI http://dx.doi.org/10.1128/aac.01707-08

CARATTOLI, A., MIRIAGOU, V., BERTINI, A., LOLI, A., COLINON, C.C VILLA, L., WHICHARD, J.M., ROSSOLINI, G.M. 2006. Replicon typing of plasmids encoding resistance to newer beta-lactams. Emerging Infectious

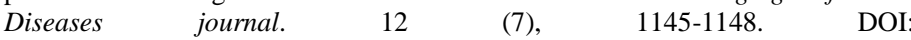
http://dx.doi.org/10.3201/eid1207.051555

CHANG, C.C., CHEN, W.C., HO, T.F., WU, H.S., WEI, Y.H. 2011 Development of natural anti-tumor drugs by microorganisms. Journal of Bioscience and Bioengineering. 111, (5), 501-511. DOI: http://dx.doi.org/10.1016/j.jbiosc.2010.12.026

FELSENSTEIN, J. 1985. Confidence limits on phylogenies: an approach using the bootstrap. Evolution. 39 (4), 783-791. DOI: http://dx.doi.org/10.2307/2408678

GORDON, E., BARNETT, D.A., HANDARHAN, J.E., HOR-NAY-PANG, C. 1974. Nocardia coeliaca, Nocardia autotrophica and the nocardin strains International Journal of Systematic and Evolutionary Microbiology. 24 (1), 54 63. DOI: http://dx.doi.org/10.1099/00207713-24-1-54

GUPTA, R.S. 2011. Origin of diderm (Gram-negative) bacteria: antibiotic selection pressure rather than endosymbiosis likely led to the evolution of bacterial cells with two membranes. Antonie Leeuwenhoek. 100 (2), 171-182. DOI: http://dx.doi.org/10.1007/s10482-011-9616-8

HAYAKAWA, M., NONOMURA, H. 1987. Humic acid-vitamin agar, a new medium for the selective isolation of soil actinomycetes. Journal of Fermentation Technology. $65 \quad$ (5), 501-509. $\quad$ DOI: http://dx.doi.org/10.1016/0385 6380(87)90108-7

JOHNSON, J.A., CITARASU, T., MARY-HELEN, P.A. 2012. Screening of antibiotic producing actinomycetes from streams. Journal of Chemical, Biological and Physical Sciences. 2 (3), 1363-1370.

JUKES, T.H., CANTOR, C.R. Evolution of protein molecules in Mammalian Protein Metabolism. In: MUNRO, H.N. 1969. Mammalian protein metabolism Academic Press, New York. 3, 21-132.

KALINOVSKAYA, N.I., KALINOVSKY, A.I., ROMANENKO, L.A., DRITRENOK, P.S., KUZNETSOVA, T.A. 2010. A New angucyclines and antimicrobial diketopiperazines from the marine mollusk-derived actinomycete Saccharothrix espanaensis An 113. Natural Product Communications. 5 (4) 597-602.

KARTHIK, L., KUMAR, G., RAO, K.V.B. 2013. Antioxidant activity of newly discovered lineage of marine actinobacteria. Asian Pacific Journal of Tropical Medicine. 6 (4), 325-332. DOI: http://dx.doi.org/10.1016/S1995-7645(13)600656

KELLY, K.L., JUDD, D.B. 1976. Color. Universal language and dictionary of names. National Bureau of Standards Special Publication 440.U.S. Department of Commerce, Washington D.C.

KIM, O.S., CHO, Y.J., LEE, K., YOON, S.H., KIM, M., NA, H., PARK, S.C., JEON, Y. S., LEE, J.H., YI, H., WON, S., CHUN, J. 2012. Introducing EzTaxone: a prokaryotic 16S rRNA Gene sequence database with phylotypes that represent uncultured species. International Journal of Systematic and Evolutionary Microbiology. 62 (3), 716-721. DOI: http://dx.doi.org/10.1099/ijs.0.038075-0

LABEDA, D.P., TESTA, R.T., LECHEVALIER, M.P., LECHEVALIER, H.A 1984. Saccharothrix, a new genus of the Actinomycetales related to Nocardiopsis. International Journal of Systematic and Evolutionary Microbiology. 34 (4), 426-431. DOI: http://dx.doi.org/10.1099/00207713-34-4426

LAMARI, L., ZITOUNI, A., BOUDJELlA, H., BADJI, B., SABAOU, N., LEBRIHI, A. 2002. New dithi- olopyrrolone antibiotics from Saccharothrix sp. 
SA 233 I. Taxonomy, production, isolation and biological properties. Journal of Antibiotics. 55 (8), 696-701. DOI: http://dx.doi.org/10.1002/chin.200308205

LARKIN, M.A., BLACHSHIELDS, G., BROWN, N.P., CHENNA, R., PA, M., MCWILIAM, H., VALENTIN, F., WALLACE, I.M., WILM, A., LOPEZ, R., THOMPSON, J.D., GIBSON, T.J., HIGGINS, D.G. 2007. CLUSTALW and CLUSTALX version 2. Bioinformatics. 23 (21), 2947-2948. DOI http://dx.doi.org/10.1093/bioinformatics/btm404

LAZZARINI, A., CAVALETTI, L., TOPPO, G., MARINELLI, F. 2001. Rare genera of actinomycetes as potential producers of new antibiotics. Antonie Leeuwenhoek. 78, 399-405. DOI: http://dx.doi.org/10.1023/a:1010287600557

LI, W.J., XU, P., SCHUMANN, P., ZHANG, Y. Q., PUKALL, R., XU, L.H., STACKEBRANDT, E., JIANG, C. L. 2007. Georgenia ruanii sp. nov., a novel actinobacterium isolated from forest soil in Yunnan (China), and emended description of the genus Georgenia. International Journal of Systematic and Evolutionary Microbiology. $57 \quad$ (7), 1424-1428. DOI http://dx.doi.org/10.1099/ijs.0.64749-0

MARCHAL, N., BOURDON, J.L. 1973. Milieux de culture et identification biochimique des bactéries. Doin press. Paris.

MARCHAL, N., BOURDON, J.L., RICHARD, C.L. 1978. Les milieux de culture pour l'isolement et l'identification biochimique des bactéries. Doin Press, Paris.

MERROUCHE, R., BOURAS, N., COPPEL, Y., MATHIEU, F., SABAOU, N., LEBRIHI, A. 2011. New dithiolopyrrolone antibiotics induced by adding sorbic acid to the culture medium of Saccharothrix algeriensis NRRL B-24137. FEMS Research letter. 318 (1), 41-46. DOI: http://dx.doi.org/10.1111/j.15746968.2011.02246.x

PATHOM-AREE, W., WARD, A.C., HORIKOSHI, K., BULL, A.T., GOODFELLOW, M. 2006. Diversity of actinomycetes isolated from the Challenger Deep sediment (10898 m) from the Mariana Trench. Extremophiles. 10 (3), 181-189. DOI: http://dx.doi.org/10.1007/s00792-005-0482-z

RAINEY, F.A., WARD-RAINEY, N., KROPPENSTEDT, R.M., STACKEBRANDT, E. 1996. The genus Nocardiopsis represents a phylogenetically coherent taxon and a distinct actinomycete lineage; proposal of Nocardiopsaceae fam. nov. International Journal of Systematic and Evolutionary Microbiology. 46 (4), 1088-1092. DOI: http://dx.doi.org/10.1099/00207713-464-1088

SABAOU, N., BOUDJELLA, H., BENNADJI, A., MOSTEFAOUI, A. ZITOUNI, A., LAMARI, L., BENNADJI, H. 1998. Les sols des oasis du Sahara algérien, source d'actinomycètes, rares producteurs d'antibiotiques. Sécheresse. 9 (2), 147-153.

SAITOH, K., SUSUKI, K., HIRANO, M., FURUMAI, T., OKI, T. 1993. Pradimicins FS and FB, new pradimicin analogs: directed production, structures and biological activities. The Journal of Antibiotics. 46 (3), 398-405. DOI: http://dx.doi.org/10.7164/antibiotics.46.398

SAITOU, N., NEI, M. 1987. The neighbor-joining method: a new method for reconstructing phylogenetic trees. Molecular Biology and Evolution. 4 (4), 406425 .

SCHIMANA, J., GEBHARDT, K., HOLTZEL, A., SCHMID, D.G., SUSSMUTH, R., MULLER, J., PUKALL, R., FIEDLER, FIEDLER, H.P. F. 2002. Arylomycins A and B, new biaryl-bridged lipopeptide antibiotics by Streptomyces sp. Tü 6075. I. Taxonomy, fermentation, isolation and biological activities. The Journal of Antibiotics. 55 (6), 565-570. DOI: http://dx.doi.org/10.7164/antibiotics.55.565

SHIRLING, B., GOTTLIEB, D. 1966. Methods for characterization of Streptomyces species. International Journal of Systematic and Evolutionary Microbiology. 16 (3), 313-340. DOI: http://dx.doi.org/10.1099/00207713-16-3313

SINGH, M.P., PETERSEN, P.J., WEISS, W.J., KONG, F, GREENSTEIN, M. 2000. Saccharomicins, novel heptadecaglycoside antibiotics produced by Saccharothrix espanaensis: Antibacterial and mechanistic activities. Antimicrobial Agents and Chemotherapy. 44 (8), 2154-2159. DOI http://dx.doi.org/10.1128/aac.44.8.2154-2159.2000

STACKEBRANDT, E., GOEBEL, B.M. 1994. Taxonomic Note: A Place for DNA-DNA reassociation and 16s rRNA sequence analysis in the present species definition in bacteriology. International Journal of Systematic and Evolutionary Microbiology. 44 (4), 846-849. DOI: http://dx.doi.org/10.1099/00207713-44-4846

SUBRAMANI, R., AALBERSBERG, W. 2012. Marine actinomycetes: An ongoing source of novel bioactive metabolites. Microbiological Research. 167 (10), 571-580. DOI: http://dx.doi.org/10.1016/j.micres.2012.06.005

TAMURA, K., PETERSON, D., PETERSON, N., STECHER, G., NEI, M., KUMAR, S. 2011. MEGA5: molecular evolutionary genetics analysis using maximum likelihood, evolutionary distance, and maximum parsimony methods. Molecular Biology and Evolution. 28 (10), 2731-3729. DOI: http://dx.doi.org/10.1093/molbev/msr121

TOMITA, K., ODA, N., HOSHINO, Y., OHKUSA, N., CHIKAZAWA, H. 1991. Fluvirucins A1, A2, B1, B2, B3, B4 and B5, new antibiotics active against influenza A virus. IV. Taxonomy on the producing organisms. Journal of Antibiotics. 44 (9), 940-948. DOI: http://dx.doi.org/10.7164/antibiotics.44.940
WANG, X., TABUDRAVU, J.T, JASPARS, M., DENG, H. 2013. Tianchimycins A-B, 16-membered macrolides from the rare actinomycete Saccharothrix xinjiangensis. Tetrahedron. 69 (30), 6060-6064. DOI http://dx.doi.org/10.1016/j.tet.2013.05.094

WAYNE, L.G., BRENNER, D.J., COLWELL, R.R., GRIMONT, P.A.D., KANDLER, O., KRICHEVSKY, M.I., MOOR, L.H., MOOR, W.E.C., MURRAY, R.G.E., STACKEBRANDT, E., STARR, M.P., TRÜPER, H.G. 1987. International Committee on Systematic Bacteriology. Report of the ad hoc committee on reconciliation of approaches to bacterial systematics. International Journal of Systematic and Evolutionary Microbiology. 37 (4), 463-464. DOI: http://dx.doi.org/10.1099/00207713-37-4-463

ZAKHAROVA, O.S., ZENOVA, G.M., ZVIAGINSEV, D.G. 2003. Selective isolation of actinomycetes of the genus Actinomadura from soil. Mikrobiologiia. $72(1), 126-130$

ZHANG, Y.Q., LIU, H.Y., CHEN, J., YUAN, L.J., SUN, W., ZHANG, L.X., ZHANG, Y. Q., YU, L.Y., LI, J.W. 2010. Diversity of culturable actinobacteria from Qinghai-Tibet plateau, China. Antonie Leeuwenhoek. 98 (2), 213-223. DOI http://dx.doi.org/10.1007/s10482-010-9434-4

ZITOUNI, A., BOUDJELLA, H., LAMARI, L., BADJI, B., MATHIEU, F., LEBRIHI, A., SABAOU, N. 2005. Nocardiopsis and Saccharothrix genera in Saharan soils in Algeria: Isolation, biological activities and partial characterization of antibiotics. Research in Microbiology. 156 (10), 984-993. DOI: http://dx.doi.org/10.1016/j.resmic.2005.05.006

ZITOUNI, A., BOUDJELLA, H., MATHIEU, F., SABAOU, N., LEBRIHI, A 2004. Mutactimycin PR, a new anthracycline antibiotic from Saccharothrix sp. SA 103. Taxonomy, fermentation, isolation and biological activities. The Journal of Antibiotics. 57 (6), 367-372. DOI: http://dx.doi.org/10.7164/antibiotics.57.367 ZITOUNI, A., LAMARI, L., BOUDJELLA, H., BADJI, B., SABAOU, N., GAOUAR, A., MATHIEU, F., LEBRIHI, A., A. LABEDA D.P. 2004 Saccharothrix algeriensis sp. nov., isolated from Saharan soil. International Journal of Systematic and Evolutionary Microbiology. 54 (4), 1377-1381. DOI: http://dx.doi.org/10.1099/ijs.0.02679-0 